\title{
CEO/CFO Relevance and Corporate Earnings Management
}

\author{
Mengzhen Wu \\ College of Economics, Jinan University, Guangzhou, China \\ Email: wumengzhen_16@163.com
}

How to cite this paper: Wu, M.Z. (2019) $\mathrm{CEO} / \mathrm{CFO}$ Relevance and Corporate Earnings Management. Modern Economy, 10, 778-796.

https://doi.org/10.4236/me.2019.103052

Received: February 21, 2019

Accepted: March 18, 2019

Published: March 21, 2019

Copyright $\odot 2019$ by author(s) and Scientific Research Publishing Inc. This work is licensed under the Creative Commons Attribution International License (CC BY 4.0).

http://creativecommons.org/licenses/by/4.0/

\begin{abstract}
It's a fact that the CEO-CFO connection will be tighter if they have appointment relationships, which may lead to the disfunction of CFOs in regulating and supervising corporate financial activities. In order to explore the actual influence of CEO-CFO connections, we studied the correlation between $\mathrm{CEO}-\mathrm{CFO}$ connectedness and the degree of corporate earnings management using the China listed company data from year 2005 to 2014. Results showed that CEO-CFO connections will increase corporate earnings management after considering the year fixed effect and the industry fixed effect. We control for corporate operation, CEO background and corporate governance factors. Further regressions are done using grouped samples divided by company size and ownership structure. The findings remain solid even after considering of numbers of robustness tests. Besides, we find that CEO duality and equity incentive will enhance the positive relationship.
\end{abstract}

\section{Keywords}

CEO-CFO Connectedness, Corporate Earnings Management, CEO Duality, Equity Incentive, CEO Overconfidence

\section{Introduction}

According to the Upper Echelon theory, background of executives could influence the corporate decision-making process (Hambrick and Mason, 1984) [1]. Recently, more and more scholars are intrigued by the correlation between traits of executives and the corporate behavior and performance (He and Liu, 2010; Bernile et al., 2017) [2] [3]. In corporate executives, CEOs and CFOs are particularly concerned by scholars because of the importance and particularity of their posts. The impact of these executives on the company's operations has been adequate. But there are very few literatures discussing their relationship and the 
impact of this association on the company's operational decisions.

In logical point of view, CFO's decision-making may be affected by the CEO. On the one hand, the CEO devotes much attention to CFO's selection.CFO may be crony of the chairman, or the CEO's supporter. On the other hand, CFO's selection is influenced by the CEO. Due to engaging system, CEO can appoint CFO directly or play an important role in the process of appointing CFO. One of the main responsibilities of the CFO is the company's financial decisions and financial reports. Strong relationship correlation between CEO and CFO may cause lower financial principles and finally affect quality of accounting information. Based on this understanding, we mainly examine the impact of CEO/CFO relevance on corporate earnings management.

There is a relationship between CEO and executive based on tenure, because CEO may affect the appointment of executives who subsequently take up since then (Morse et al., 2011) [4]. Coles et al. (2007) [5], based on tenure, point out the index of association between CEO and board members for the first time: board co-option-whether the board member is appointed after the appointment of the CEO. This indicator can indeed be used as an alternative variable of correlation between CEO and board members, and affect the corporate performance significantly (Chidambaran, 2010) [6]. Shane et al. (2016) apply this indicator to the correlation between CEO and CFO [7]. At the same time, they point out this kind of association between the CEO and the CFO significantly affects the CEO's salary. China is a country that pays more attention to interpersonal relationship. Thus, in China, more attention should be paid to the impact of the correlation between executives on corporate governance. Among the executives, CEO and CFO are two important positions, which we should explore whether the two are cooperating or supervising each other. For now, existing literatures little focus on the impact of the association between CEO and CFO on corporate earnings in China.

Earnings information is one of the important indexes of accounting information quality. At the same time, earnings management can seriously damage earnings quality (Lo, 2008; Liu H.L., 2014) [8] [9]. As is known to all, earnings management can cause financial information users to misjudge status of the corporate and damage the interests of investors. Furthermore, Earnings management may result in improper capital allocation and increased instability in financial markets as well. Therefore, earnings management has been a topic close attention to regulators, investors and business managers.

In fact, $\mathrm{CEO}$ and $\mathrm{CFO}$ together need to be responsible for the true validity of the disclosed financial information. In this way, the financial statements of listed companies are valid. It can be seen that both CEO and CFO have a critical impact on the authenticity of the company's financial information. Therefore, the $\mathrm{CEO}$ and CFO should supervise each other. However, the fact is that, for maximizing his or her own interest, the CEO sometimes has "concealed", "whitewashed" or even tampered with financial information. Does the CFO prevent or support the CEO's misconduct? 
Based on the above analysis, this paper tries to answer the following questions. Firstly, whether can the CEO/CFO relevance affect the company earnings management level? Secondly, if so, how does it arise?

This paper attempts to analyze the relationship between CEO/CFO relevance and the company's earnings management level. The empirical study finds a significant and positive correlation between $\mathrm{CEO} / \mathrm{CFO}$ relevance and the level of corporate earnings management. The results are still significant considering for operational status, CEO background and the level of supervision.

Our contribution lies in the following three points. Firstly, literatures have discussed the impact of term heterogeneity on companies. On the one hand, heterogeneity gives the company a negative impression because it leads to a decrease in the frequency of communication and cohesion. On the other hand, heterogeneity will lead to a decline in the level of earnings management, so it has a positive impact on the company. This paper chooses another perspective-the CEO and CFO tenure homogeneity, providing new evidence for the impact of the relationship between executives on corporate behavior. Secondly, it has been found in the literature that both $\mathrm{CEO}$ and CFO terms can affect earnings management. This article explores the relationship between CEO and CFO from the perspective of appointment, which can provide new evidence for the impact of managerial tenure on earnings management. Thirdly, this paper also has certain reference value for the practice and supervision of human resources management, such as the appointment of CEOs and CFOs.

The remainder of this paper is organized as follows. We first provide a literature review of the current research. Then, we develop a research model, variables and the corresponding research hypotheses. Next, we present an empirical study and robustness test. And we analyze the moderating effect as well as channels. Finally, we discuss the findings and draw some expectations for research and practice.

\section{Literature Review and Hypotheses}

\subsection{CEO Power Based on Appointment}

Existing literatures find that the power of CEO can influence the behavior of enterprises. Highly centralized CEO is more adept at mobilizing the company's resources to improve internal controls and thus control the quality of accounting information effectively. It is also found that if the CEO has the greater right, the earnings management of listed companies will be higher (Zhou D.H., 2014) [10]. When the CEO power is weak, the company's audit committee's financial skills are negatively correlated with the company's internal control. When the CEO power is strong, the negative correlation between the two will be reduced. Thus, the degree of internal control of the company depends on the size of the CEO's rights. (Lisic, 2015) [11]. However, these all study the influence of CEO's power prescribed by law on corporate behavior and have no in-depth researches about the influence of CEO interpersonal relationship. 
The existing literature divides the CEO relationship into the CEO career relationship based on the appointment system and the relationship network based on the previous education, work and social organization. The former refers to the CEO's influence in the executives who took office during his term. And this influence is generally measured by the proportion of other executives and directors taking office in the current term of office (Khanna and $\mathrm{Lu}, 2015$ ) [12]. The link increases the sociologist's so-called "social influence" based on criteria for reciprocity, liking, and social coherence to form group decision-making processes. Social influence is conducive to getting acquiescence or even support in the case of illegal activities. When more executives take office during the CEO tenure, the CEO's influence will increase. Probably because the CEO was involved in the process of hiring, nominating and appointing executives (Morse et al., 2011) [4]. These executives are therefore more likely to have a common belief and opinion with the current CEO. At the same time, they are also more likely to be loyal to the CEO who hires or promotes them, comparing to executives appointed by the former CEO (Landier et al., 2013) [13]. For CEOs, they are usually willing to participate in the appointment of board members, either directly appointed or nominated. Therefore, the board of directors who took office during the tenure of the CEO may be more loyalty to the CEO (Coles et al., 2014) [14]. In other words, the relationship between the CEO and the business leaders under the appointment system will weaken the balance between regulatory function and internal powers.

In addition, the association between CEO and other executives may increase or decrease the incidence rate of corporate fraud (Khanna and Lu, 2015) [12]. $\mathrm{CEO}$ is one of the top decision-makers in the company and has motivation to use their own rights to make accounting information communicated to the general public in line with their expectations, whether to show his or her ability in front of shareholders or for higher pay. Just like other activities of corporate, CEO's earnings management behavior often requires the support or acquiescence of executives and (or) directorate. The closer contact between CEO and CFO may facilitate the corporate's misconduct and provide the necessary support.

\subsection{CEO/CFO Relevance}

CEO has the motivation to manage earnings. While its real implementation requires CFO's professional skills and cooperation. Therefore, the CEO's influence on CFO may affect whether CEO can successfully manage earnings. Existing literatures mainly discuss the association between CEO and CFO in two aspects: background difference and job difference.

CEO and CFO with the same personal background and social relationship can significantly affect the corporate earnings management. When owning the same background or social relationship, the relationship between CEO and CFO is much tighter, CFO is more willing to help the CEO, and there is an increased likelihood of earnings management in the company (Gopal et al., 2011) [15].

On the other hand, differences in tenure are determined mainly by time of 
appointment, time of departure and tenure. Studies show that CEO and CFO served at different times can affect the quality of corporate accounting information exposed to the outside world. And even further research shows that CEO and CFO served at different times can reduce the company's earnings management level (Liu J.Y., 2013) [16]. At the same time, when the CEO power is larger, the situation that CEO and CFO served at different times has a lower impact on the company's positive earnings management compared to smaller power. Meanwhile, when the CEO has a greater impact on the $\mathrm{CFO}, \mathrm{CFO}$ is more inclined to cooperate with CEO for immoral behavior (Jiang F.X. et al., 2013) [17]. Differences in CEO and CFO tenure may lead to mutual exclusion and reduce communication frequency and cohesion. This can make it difficult for them to reach a consensus when making decisions.

There is no in-depth study of CEO's influence on CFO's impact on earnings management. Therefore, we refined the CEO's influence on the CFO and study this "soft" influence on the basis of the appointment system-what is the relationship between $\mathrm{CEO} / \mathrm{CFO}$ relevance and earnings management.

\subsection{Hypotheses}

Since both shareholders and investors cannot access to the inside view of a corporate, they need to integrate and analysis all available financial information. At the same time, the incentive mechanism and the shareholder appointment system will associate the personal interests of the $\mathrm{CEO}$ with the business situation. In this case, the CEO has the motivation to adjust the corporate earnings. The CFO's particularity may determine whether the CEO can successfully implement this behavior. Based on the above theoretical research, this paper will examine the impact of $\mathrm{CEO} / \mathrm{CFO}$ relevance on the company from the perspective of corporate earnings management and make the following assumption:

H0: If CEO and CFO have tenure relation, the listed company's information disclosure quality will be lower. In other words, the level of earnings management of listed companies will be higher.

\section{Research Model}

\subsection{Sample Selection and Data Source}

To explore the impact of CEO/CFO relevance on earnings management of listed companies, we select Chinese A-share listed companies from 2005 to 2014 as a sample and filter the data as following: 1) We eliminate financial companies, because such listed companies have a special accounting and reporting system and principles of financial statements and capital structure are also different from those of ordinary listed companies. 2) We exclude listed companies in ST or *ST from 2005 to 2014, because there are some problems in company's financial situation, capital structure and governance behavior.

After that, we remove the missing observations. In general, we obtain 14,297 observations of 1934 listed companies during the sample period. The data comes 
mainly from the Wind database and the CSMAR database. The indictor Con measuring the $\mathrm{CEO} / \mathrm{CFO}$ relevance is sorted out by hand.

\subsection{Model Design and Variable Descriptions}

This paper uses the following model to test the relationship between $\mathrm{CEO} / \mathrm{CFO}$ relevance and earnings management of listed companies.

$$
\operatorname{absEM}_{i t}=\alpha_{0}+\alpha_{1} \operatorname{con}_{i t}+\alpha_{2} \text { Controls }_{i t}+\text { Year }_{\mathrm{t}}+\text { Industry }_{i}+\mu_{i t}
$$

In empirical analysis, we deal with the data as following. 1) In order to eliminate the interference of extreme values, we winsorize the accounting data for $5 \%$. 2) The standard deviations of the coefficients in the model are clustered into the corporate level.

1) Explain variables-Earnings management

According to existing literatures, we use the modified Jones model (Dechow et al., 1995) to estimate the degree of earnings management [18]. Specifically, we use the following equation to estimate:

$$
\begin{gathered}
\mathrm{TA}_{t} / \text { Asset }_{t-1}=\alpha_{1} / \text { Asset }_{t-1}+\alpha_{2} \Delta \mathrm{REV}_{t} / \text { Asset }_{t-1}+\alpha_{3} \mathrm{PPE}_{t} / \text { Asset }_{t-1}+\varepsilon \\
\mathrm{EM}=\mathrm{TA}_{t} / \text { Asset }_{t-1}-\left[\hat{\alpha}_{1} / \text { Asset }_{t-1}+\hat{\alpha}_{2}\left(\Delta \mathrm{REV}_{t}-\Delta \mathrm{REC}_{t}\right) / \text { Asset }_{t-1}+\hat{\alpha}_{3} \mathrm{PPE}_{t} / \text { Asset }_{t-1}\right]
\end{gathered}
$$

In equation, TA refers to the total accrual item, which is equal to the operating profit minus the net cash flow from cash activities. Asset refers to the total assets of the company. $\triangle \mathrm{REV}$ refers to the increase in operating income. $\triangle \mathrm{REC}$ is the increase in accounts receivable. And PPE is a fixed asset.

At the same time, we considered the uncorrected Jones model (Jones, 1991) to estimate the degree of earnings management for robustness testing [19]. The method is shown below:

$$
\begin{gathered}
\mathrm{TA}_{t} / \text { Asset }_{t-1}=\alpha_{1} / \text { Asset }_{t-1}+\alpha_{2} \Delta \mathrm{REV}_{t} / \mathrm{Asset}_{t-1}+\alpha_{3} \mathrm{PPE}_{t} / \text { Asset }_{t-1}+\varepsilon \\
\mathrm{EM}=\mathrm{TA}_{t} / \text { Asset }_{t-1}-\left(\hat{\alpha}_{1} / \text { Asset }_{t-1}+\hat{\alpha}_{2} \Delta \mathrm{REV}_{t} / \text { Asset }_{t-1}+\hat{\alpha}_{3} \mathrm{PPE}_{t} / \text { Asset }_{t-1}\right)
\end{gathered}
$$

We all use absolute values to represent the size of the earnings management. The larger value represents the higher the degree of earnings management, otherwise, lower.

2) Explain variables-CEO/CFO relevance

When a new CEO takes office, he may affect the appointment of new board members (Shivdasani and Yermack, 1999) [20]. After that, Jeffrey et al. (2007) point out the index of association between CEO and board members: board co-option-whether the board member is appointed after the appointment of the CEO [5]. Chidambaran (2010) uses this indictor as an alternative variable of correlation between CEO and board members, and his study shows that it indeed affects the corporate performance significantly [6].

Morse et al. (2011) point out that influence of the CEO may increase when more executives take office during this CEO tenure, because the CEO participates in the process of recruitment, nomination and appointment of executives [4]. Shane et al. (2016) use this method to measure the association between the 
$\mathrm{CEO}$ and the $\mathrm{CFO}$, and empirical results show that the relevance does have a significant positive impact on CEO's pay [7].

Based on the method of measurement in the existing literature, the explanatory variable (con) is defined as whether the appointment of the CFO is after the CEO takes office.

3) Control variables

Company size, solvency, profitability, asset liquidity and other factors will affect the listed company's earnings management behavior. With reference to previous studies, we considered the company's operating conditions, the CEO's personal background and the company's regulatory level, and the control variables we selected are as follows (See Table 1).

\subsection{Descriptive Statistics}

Table 2 reports the descriptive statistical results.

As can be seen from the statistics, for $\mathrm{CEO} / \mathrm{CFO}$ relevance, the median is 1 and the mean is 0.29 . The ratio of relationship based on appointment system between $\mathrm{CEO} / \mathrm{CFO}$ was $62.9 \%$, which is in line with the initial guess which listed companies focus on interpersonal relationships. The median level of earnings management is 0.0513 . At the level of corporate supervision, the average number of directors of listed companies is about 9 . The average number of supervisors in China is about 4. In terms of CEO's personal background, CEO's average term is about 6 years. CEO's average age is 47.67 years old and male CEO accounts for $94.4 \%$, which means most CEOs are middle-aged men. At the same time, in terms of CEO education, the mean is 2.526 and the median is 3 . This indicates that most CEOs of listed company have higher diploma-master's degree or doctorate-in China (See Table 2).

Table 1. Control variables.

\begin{tabular}{|c|c|}
\hline Variables & Definition \\
\hline LN_A & The size of the listed company, the natural logarithm of the company's total assets \\
\hline Lev & Asset-liability ratio $=$ total liabilities/total assets \\
\hline ROA & Return on Assets $=($ Total Profit + Interest Expenditure $) /$ Total Assets \\
\hline Netprofit & Net profit \\
\hline ReceiR & Accounts Receivable Ratio = Accounts Receivable/Revenue from principal operations \\
\hline TQ & Tobin Q value \\
\hline Tenure & Tenure of CEO \\
\hline Gender & Gender of CEO, 1 male, 2 female. \\
\hline Education & $\begin{array}{l}\text { Education of CEO, 1training school, 2Bachelor degree, 3Master degree, 4Doctoral } \\
\text { degree }\end{array}$ \\
\hline Age & Age of CEO \\
\hline N_Director & Number of board members \\
\hline N_Supervisor & The number of members of the Supervisory Board \\
\hline N_Manager & Number of executives \\
\hline meeting & Number of Board Meetings \\
\hline
\end{tabular}


Table 2. The descriptive statistics of variables.

\begin{tabular}{ccccccc}
\hline variable & $\mathrm{N}$ & mean & $\mathrm{p} 50$ & $\mathrm{sd}$ & $\min$ & $\max$ \\
\hline absEM & 14297 & 0.0840 & 0.0513 & 0.180 & $1.18 \mathrm{e}-06$ & 7.076 \\
con & 14297 & 0.629 & 1 & 0.483 & 0 & 1 \\
LN a & 14297 & 21.81 & 21.68 & 1.290 & 12.31 & 28.51 \\
Lev & 14297 & 48.94 & 49.69 & 19.83 & 13.59 & 83.24 \\
ROA & 14297 & 6.036 & 5.519 & 14.45 & -198.4 & 1062 \\
ReceiR & 14297 & 0.173 & 0.124 & 0.164 & 0.00374 & 0.600 \\
Netprofit & 14297 & $4.430 \mathrm{e}+08$ & $8.200 \mathrm{e}+07$ & $3.710 \mathrm{e}+09$ & $-1.700 \mathrm{e}+10$ & $1.510 \mathrm{e}+11$ \\
Tq & 14297 & 2.201 & 1.796 & 1.221 & 0.512 & 5.571 \\
Stateshr & 14297 & 11.95 & 0 & 20.26 & 0 & 76.49 \\
age & 14297 & 47.67 & 47 & 6.425 & 24 & 75 \\
gender & 14297 & 0.944 & 1 & 0.230 & 0 & 1 \\
tenure & 14297 & 6.005 & 5.417 & 3.765 & 0 & 21.58 \\
education & 14297 & 2.526 & 3 & 0.787 & 1 & 4 \\
N_director & 14297 & 9.109 & 9 & 1.857 & 4 & 19 \\
N_manager & 14297 & 6.438 & 6 & 2.481 & 1 & 45 \\
N_supervisor & 14297 & 3.883 & 3 & 1.277 & 0 & 13 \\
meeting & 14297 & 9.105 & 8 & 3.767 & 1 & 57 \\
\hline & & & & & & \\
\hline
\end{tabular}

\section{Research Results}

\subsection{Basic Regression Results}

In order to detect the impact of $\mathrm{CEO} / \mathrm{CFO}$ relevance on corporate earnings management, our results are shown in Table 3 . The first column simply returns the $\mathrm{CEO} / \mathrm{CFO}$ relevance to the company's earnings management level, and we achieve the initial relationship between CEO/CFO relevance and the level of earnings management of listed companies. As is shown, the coefficient of $\mathrm{CEO} / \mathrm{CFO}$ relevance to earnings management is significant at the $5 \%$ level and the symbol is positive. This indicates the higher the earnings management level of listed companies with $\mathrm{CEO} / \mathrm{CFO}$ relevance as we assume. Based on the first column, the second column joins control variables-company size, solvency, profitability, asset liquidity and other related companies operating level variables. The coefficient is still significant at the $5 \%$ level and the symbol is positive, which means the conclusion is still established. At this point, we can get an initial conclusion that if CEO has a close relationship with CFO on the basis of the appointment system, the manipulative accrual margin of the listed company will be higher than that of the company that does not have such a relationship (See Table 3).

The third and fourth columns of Table 3 add the control variables of the CEO's personal characteristics and corporate supervision level in turn, and the 
Table 3. CEO/CFO relevance and corporate earnings management.

\begin{tabular}{|c|c|c|c|c|}
\hline & (1) & (2) & (3) & $(4)$ \\
\hline \multirow[t]{2}{*}{ con } & $0.0044^{\star *}$ & $0.0047^{\star \star}$ & $0.0111^{\star * *}$ & $0.0107^{\star * *}$ \\
\hline & $(2.10)$ & $(2.20)$ & $(3.87)$ & $(3.83)$ \\
\hline \multirow[t]{2}{*}{ LN_a } & & $-0.0041^{\star * *}$ & $-0.0025^{\star *}$ & 0.0005 \\
\hline & & $(-2.97)$ & $(-2.02)$ & $(0.27)$ \\
\hline \multirow[t]{2}{*}{ Lev } & & $0.0008^{\star * \star}$ & $0.0008^{\star * \star}$ & $0.0008^{* * *}$ \\
\hline & & $(5.47)$ & $(5.72)$ & $(5.55)$ \\
\hline \multirow[t]{2}{*}{ ReceiR } & & $0.0204^{\star *}$ & $0.0170^{*}$ & 0.0153 \\
\hline & & $(2.33)$ & $(1.82)$ & $(1.67)$ \\
\hline \multirow[t]{2}{*}{$\mathrm{Tq}$} & & $0.0121^{\star * *}$ & $0.0123^{\star * *}$ & $0.0124^{* * *}$ \\
\hline & & $(8.15)$ & $(8.27)$ & $(8.01)$ \\
\hline \multirow[t]{2}{*}{ Netprofit } & & $-2.45 e-13$ & $-3.08 \mathrm{e}-13$ & $-2.51 e-13$ \\
\hline & & $(-1.36)$ & $(-1.50)$ & $(-0.88)$ \\
\hline \multirow[t]{2}{*}{ ROA } & & 0.0004 & 0.0004 & 0.0004 \\
\hline & & $(1.27)$ & $(1.30)$ & $(1.30)$ \\
\hline \multirow[t]{2}{*}{ Stateshr } & & 0.0002 & 0.0002 & 0.0002 \\
\hline & & $(1.26)$ & $(1.13)$ & $(1.32)$ \\
\hline \multirow[t]{2}{*}{ age } & & & -0.0001 & -0.0001 \\
\hline & & & $(-0.58)$ & $(-0.44)$ \\
\hline \multirow[t]{2}{*}{ gender } & & & $-0.0087^{*}$ & -0.0065 \\
\hline & & & $(-1.77)$ & $(-1.36)$ \\
\hline \multirow[t]{2}{*}{ tenure } & & & $-0.0027^{\star * *}$ & $-0.0026^{* * *}$ \\
\hline & & & $(-3.19)$ & $(-2.96)$ \\
\hline \multirow[t]{2}{*}{ education } & & & $-0.0035^{\star * *}$ & $-0.0034^{* * *}$ \\
\hline & & & $(-2.85)$ & $(-3.00)$ \\
\hline \multirow[t]{2}{*}{ N_director } & & & & $-0.0027^{\star * *}$ \\
\hline & & & & $(-2.81)$ \\
\hline \multirow[t]{2}{*}{ N_manager } & & & & $-0.0026^{* * *}$ \\
\hline & & & & $(-3.98)$ \\
\hline \multirow[t]{2}{*}{ N_supervisor } & & & & -0.0028 \\
\hline & & & & $(-1.32)$ \\
\hline \multirow[t]{2}{*}{ meeting } & & & & 0.0003 \\
\hline & & & & $(0.58)$ \\
\hline $\mathrm{N}$ & 14297 & 14297 & 14297 & 14297 \\
\hline INDUSTRY & YES & YES & YES & YES \\
\hline YEAR & YES & YES & YES & YES \\
\hline
\end{tabular}

Notes: ${ }^{*} \mathrm{p}<0.1 ;{ }^{* *} \mathrm{p}<0.05 ;{ }^{* * *} \mathrm{p}<0.01$.OLS with standard errors clustered by listed company.

correlation degree still has a significant positive correlation with the company's earnings management level. 
In third columns, CEO/CFO correlation degree still has a significant and positive impact on the earnings management level of listed companies in the case of CEO personal background variables (CEO's gender, education level and age). It is worth mentioning that the listed company CEO's tenure and level of education both have significant negative correlation for the level of earnings management of listed companies. In other words, if CEO of the listed company has the longer tenure and the higher the degree of education, the level of earnings management will be lower. However, the gender of the CEO also affects the level of corporate earnings management. When the CEO is female, the company's earnings management level is higher.

In the fourth column, we further add the variables of the company's supervisory level, including the number of board members, the number of supervisors and executives, and the number of board meetings. The result shows that the higher the company's regulatory level, the company's lower level of earnings management

In order to further explore the impact of $\mathrm{CEO} / \mathrm{CFO}$ relevance on earnings management of listed companies, we are further grouped for regression according to the size of the assets and corporate attributes. The regression results are shown in Table 4.

First of all, we consider the company attributes. The coefficient of state-owned enterprises is relatively larger and more significant compared to private enterprises. Possible reason is the listed companies with higher proportion of state-owned pay more attention to interpersonal relationship, and CEO plays a more important role in the CFO promotion, appointment. Therefore, CFO is more likely to follow CEO's disposal.

Then, we grouped according to the size of the assets. The results show that the greater the size of the company's assets, the greater the positive correlation of $\mathrm{CEO} / \mathrm{CFO}$ relevance to the earnings management level of listed companies. But the coefficient is relatively small. For a possible reason, the company has a relatively complete governance structure and strong supervision in the larger listed companies. CEO is relatively difficult to manipulate the financial, and thus he is more motivated to cooperate with the CFO in order to "complete" performance.

\subsection{Robustness Tests}

1) Endogenous test

Regression analysis showed that there is a significant positive correlation between CEO/CFO correlation and corporate earnings management. That is to say listed companies with tighter CEO/CFO relevance have a higher level of earnings management. But for the previous analysis, we cannot rule out endogenous problems.

In order to solve the endogenous problem, we use the PSM-re-match the $\mathrm{CEO} / \mathrm{CFO}$ relevance and verify the re-matching degree. There is still a significant positive correlation between the newly matched CEO/CFO association level and the company's earnings management level (Table 5). 
Table 4. Regressions grouped by asset scale and ownership structure.

\begin{tabular}{|c|c|c|c|c|}
\hline & (1) & (2) & (3) & (4) \\
\hline & State-owned & Private-owned & Larger-scale & Smaller-scale \\
\hline \multirow[t]{2}{*}{ con } & $0.0118^{* * *}$ & $0.0086^{*}$ & $0.0113^{* * *}$ & $0.0139^{* *}$ \\
\hline & $(3.12)$ & $(1.75)$ & $(2.76)$ & $(2.61)$ \\
\hline \multirow[t]{2}{*}{ LN_a } & -0.0006 & 0.0011 & & \\
\hline & $(-0.39)$ & $(0.29)$ & & \\
\hline \multirow[t]{2}{*}{ Lev } & $0.0007^{\star * *}$ & $0.0011^{\star * *}$ & $0.0011^{*}$ & $0.0007^{\star * *}$ \\
\hline & $(4.25)$ & $(3.64)$ & $(1.82)$ & $(3.59)$ \\
\hline \multirow[t]{2}{*}{ ROA } & 0.0008 & 0.0003 & $0.0060^{*}$ & 0.0001 \\
\hline & $(1.24)$ & $(1.24)$ & $(1.80)$ & $(0.60)$ \\
\hline \multirow[t]{2}{*}{ ReceiR } & 0.0036 & 0.0223 & $0.0497^{\star *}$ & 0.0097 \\
\hline & $(0.25)$ & $(1.27)$ & $(2.02)$ & $(1.05)$ \\
\hline \multirow[t]{2}{*}{ Netprofit } & $-6.21 e-13$ & $2.62 \mathrm{e}-11$ & $-1.39 \mathrm{e}-12$ & $-2.01 \mathrm{e}-11$ \\
\hline & $(-1.07)$ & $(1.65)$ & $(-1.26)$ & $(-0.71)$ \\
\hline \multirow[t]{2}{*}{$\mathrm{Tq}$} & $0.0087^{* * *}$ & $0.0141^{\star * *}$ & -0.0017 & $0.0118^{* * *}$ \\
\hline & $(5.50)$ & $(4.91)$ & $(-0.23)$ & $(8.23)$ \\
\hline \multirow[t]{2}{*}{ Stateshr } & & & 0.0003 & 0.0001 \\
\hline & & & $(1.63)$ & $(0.64)$ \\
\hline \multirow[t]{2}{*}{ age } & -0.0001 & $1.13 e-5$ & 0.0004 & -0.0003 \\
\hline & $(-0.27)$ & $(0.04)$ & $(0.88)$ & $(-1.42)$ \\
\hline \multirow[t]{2}{*}{ gender } & $-0.0185^{\star}$ & -0.0022 & $-0.0137^{\star}$ & -0.0004 \\
\hline & $(-1.92)$ & $(-0.30)$ & $(-1.83)$ & $(-0.07)$ \\
\hline \multirow[t]{2}{*}{ tenure } & $-0.0024^{\star * *}$ & $-0.0039^{* * *}$ & $-0.0035^{\star *}$ & $-0.0023^{* * *}$ \\
\hline & $(-2.73)$ & $(-2.80)$ & $(-2.32)$ & $(-3.35)$ \\
\hline \multirow[t]{2}{*}{ education } & $-0.0044^{*}$ & -0.0018 & -0.0027 & $-0.0035^{\star}$ \\
\hline & $(-1.89)$ & $(-0.83)$ & $(-1.01)$ & $(-1.91)$ \\
\hline \multirow[t]{2}{*}{ N_director } & $-0.0021^{\star * *}$ & $-0.0049^{*}$ & $-0.0019^{* *}$ & $-0.0035^{\star}$ \\
\hline & $(-2.90)$ & $(-1.73)$ & $(-2.59)$ & $(-1.81)$ \\
\hline \multirow[t]{2}{*}{ N_manager } & $-0.0021^{\star * *}$ & $-0.0034^{\star * *}$ & $-0.0028^{\star * *}$ & $-0.0028^{* * *}$ \\
\hline & $(-3.10)$ & $(-2.66)$ & $(-2.97)$ & $(-3.36)$ \\
\hline \multirow[t]{2}{*}{ N_supervisor } & -0.0029 & -0.0018 & -0.0034 & -0.0027 \\
\hline & $(-1.58)$ & $(-0.43)$ & $(-1.14)$ & $(-1.46)$ \\
\hline \multirow[t]{2}{*}{ meeting } & 0.0002 & -0.0006 & -0.0004 & $0.0007^{*}$ \\
\hline & $(0.60)$ & $(-0.36)$ & $(-0.43)$ & $(1.89)$ \\
\hline $\mathrm{N}$ & 7650 & 5395 & 6443 & 7853 \\
\hline INDUSTRY & YES & YES & YES & YES \\
\hline YEAR & YES & YES & YES & YES \\
\hline
\end{tabular}

Notes: ${ }^{\star} \mathrm{p}<0.1 ;{ }^{* *} \mathrm{p}<0.05 ;{ }^{* *} \mathrm{p}<0.01$.OLS with standard errors clustered by listed company. 
Table 5. Endogenous test results.

\begin{tabular}{|c|c|c|}
\hline & absEM & T-values \\
\hline treated & $0.0116^{* * *}$ & $(3.83)$ \\
\hline LN_a & 0.0012 & $(0.53)$ \\
\hline Lev & $0.0009^{* * *}$ & $(5.09)$ \\
\hline ReceiR & 0.0201 & $(1.54)$ \\
\hline $\mathrm{Tq}$ & $0.0136^{* * *}$ & $(6.91)$ \\
\hline Netprofit & $-2.45 e-13$ & $(-0.95)$ \\
\hline ROA & 0.0004 & $(1.26)$ \\
\hline Stateshr & 0.0002 & $(1.21)$ \\
\hline age & $2.81 \mathrm{e}-5$ & $(0.09)$ \\
\hline gender & -0.0061 & $(-1.10)$ \\
\hline tenure & $-0.0029^{\star *}$ & $(-2.34)$ \\
\hline education & $-0.0030^{\star \star}$ & $(-2.09)$ \\
\hline N_director & $-0.0035^{\star * *}$ & $(-2.70)$ \\
\hline N_manager & $-0.0027^{\star * *}$ & $(-3.50)$ \\
\hline N_supervisor & -0.0034 & $(-1.32)$ \\
\hline meeting & -0.0000 & $(-0.07)$ \\
\hline $\mathrm{N}$ & 10622 & \\
\hline INDUSTRY & YES & \\
\hline YEAR & YES & \\
\hline
\end{tabular}

Notes: OLS with standard errors clustered by listed company. ${ }^{*} \mathrm{p}<0.1 ;{ }^{* *} \mathrm{p}<0.05 ;{ }^{* *} \mathrm{p}<0.01$.

2) Alternative measure of earnings management index

In order to test the robustness of the empirical results, we replace the variable of earnings management. We use the revised Jones model to estimate the operational accrual margin management level. The result is still significant shown in Table 6.

3) Reducing sample size

And then, we removed data from 2008 to 2009 taking the impact of the 2008 financial crisis on Chinese listed companies into account. We test again and the result shows that the impact of relevance on earnings management is still positive and significant (See Table 7).

\subsection{Further Analysis}

1) Moderation in Equity incentive

It is a long-term management incentive that lets the management hold company stock or stock options to become corporate shareholders, so that the personal interests of management are linked to the interests of the company. It can motivate management to increase its wealth by increasing the long-term value of the company. On the one hand, the incentive requires the operator to proceed 
Table 6. Unimproved Jones model.

\begin{tabular}{|c|c|c|}
\hline & absEM2 & T-values \\
\hline con & $0.0091^{*}$ & (1.99) \\
\hline LN_a & $-0.0169^{\star * *}$ & $(-5.24)$ \\
\hline Lev & $0.0014^{\star * *}$ & $(7.18)$ \\
\hline ROA & $0.0048^{\star * *}$ & $(3.85)$ \\
\hline ReceiR & $0.0368^{* * *}$ & $(2.97)$ \\
\hline Netprofit & $-9.55 e-14$ & $(-0.22)$ \\
\hline $\mathrm{Tq}$ & 0.0044 & $(1.36)$ \\
\hline Stateshr & 0.0001 & $(0.92)$ \\
\hline age & 0.0002 & $(1.10)$ \\
\hline gender & -0.0045 & $(-0.92)$ \\
\hline tenure & $-0.0027^{* * *}$ & $(-4.24)$ \\
\hline education & -0.0016 & $(-1.04)$ \\
\hline N_director & $-0.0020^{* * *}$ & $(-3.10)$ \\
\hline N_manager & $-0.0017^{* * *}$ & $(-3.79)$ \\
\hline N_supervisor & -0.0014 & $(-1.28)$ \\
\hline meeting & 0.0005 & $(1.57)$ \\
\hline $\mathrm{N}$ & 14294 & \\
\hline INDSTRUY & YES & \\
\hline YEAR & YES & \\
\hline
\end{tabular}

Notes: OLS with standard errors clustered by listed company. ${ }^{\star} \mathrm{p}<0.1 ;{ }^{* *} \mathrm{p}<0.05 ;{ }^{* * *} \mathrm{p}<0.01$.

Table 7. Sub-sample test.

\begin{tabular}{ccc}
\hline & absEM & T-values \\
\hline con & $0.0122^{* * *}$ & $(4.04)$ \\
LN_a & 0.0004 & $(0.21)$ \\
Lev & $0.0007^{* * *}$ & $(6.14)$ \\
ROA & 0.0003 & $(1.39)$ \\
ReceiR & $0.0214^{* * *}$ & $(2.75)$ \\
Netprofit & $-1.92 \mathrm{e}-13$ & $(-0.69)$ \\
Tq & $0.0126^{* * *}$ & $(7.14)$ \\
Stateshr & 0.0001 & $(1.52)$ \\
age & 0.0001 & $(0.37)$ \\
gender & -0.0037 & $(-0.73)$ \\
tenure & $-0.0028^{* * *}$ & $(-2.94)$ \\
education & -0.0024 & $(-1.58)$ \\
N_director & $-0.0022^{* * *}$ & $(-3.28)$ \\
N_manager & $-0.0019^{* * *}$ & $(-4.39)$ \\
N_supervisor & -0.0026 & $(-1.44)$ \\
& &
\end{tabular}




\begin{tabular}{ccc}
\hline meeting & 0.0002 & $(0.32)$ \\
$\mathrm{N}$ & 11688 \\
INDUSTRY & YES \\
YEAR & YES \\
\hline
\end{tabular}

Notes: OLS with standard errors clustered by listed company. ${ }^{*} \mathrm{p}<0.1 ;{ }^{\star *} \mathrm{p}<0.05 ;{ }^{\star * *} \mathrm{p}<0.01$.

from the long-term interests of the firm, to consider the performance of the firm during his or her tenure, and to maintain such a good situation, so that it can be bound by the behavior of incentives in order to prevent its earnings management. Thereby it can promote the enterprise development and enhance the ability of enterprises to create value in the future. On the other hand, when taking equity incentives, if the greater the proportion of management's holdings, the more likely it is to make decisions and actions to reduce the likelihood of companies being acquired, merged and bankrupt. At the same time, it may greatly reduce the external market constraints on the management, and enhance the management of the company's control. In order to maximize their own interests, they can make decisions bad for the maximization of corporate value, which in turn promotes the degree of corporate earnings management.

We join the interaction between equity incentive and $\mathrm{CEO} / \mathrm{CFO}$ relevance. As can be seen from the first column of Table 8, the coefficient of interaction and the correlation coefficient are both remarkable and positive. As we can see, taking equity incentives, to a certain extent, does not play a role in restraining management and the suppression of earnings management in China listed companies. Instead, it increases the CEO's control over the company and stimulates them to accelerate earnings management cooperating with CFO (See Table 8).

2) Moderation in CEO also served as chairman

If the CEO is concurrently chairman which means the CEO also has the power of chairman, the CEO may have a significant impact on issues such as the board agenda, identify information submitted to the board, and decide on topics discussed by the board, and etc. Thus, having multiple executive positions at the same time will greatly enhance the CEO's power.

We join the interaction between $\mathrm{CEO}$ also served as chairman and $\mathrm{CEO} / \mathrm{CFO}$ relevance. In the second column of Table 8 , we discussed the adjustment effect of the CEO served as chairman. The result shows that the coefficient of the interaction term is also remarkable and positive, and the coefficient of correlation increase compared to the absence of the moderation effect. In other words, when the $\mathrm{CEO}$ has a greater power, the $\mathrm{CEO} / \mathrm{CFO}$ relevance has a significant positive impact on the level of earnings management. Possible reason is that when the $\mathrm{CEO}$ has more power, more convenient carrying out a number of informal activities, CFO is more likely to follow the arrangements of CEO (See Table 8).

3) Intermediate mechanism

We selected overconfidence as an intermediate variable. First of all, if the CEO 
Table 8. Moderation.

\begin{tabular}{|c|c|c|}
\hline & (1) & (2) \\
\hline & Equity incentive & Concurrent post \\
\hline \multirow[t]{2}{*}{ con } & $0.0145^{\star * *}$ & $0.0130^{\star * *}$ \\
\hline & $(3.48)$ & $(4.00)$ \\
\hline \multirow[t]{2}{*}{ con\#courage } & $0.0098^{*}$ & \\
\hline & $(1.97)$ & \\
\hline \multirow[t]{2}{*}{ con\#cochair } & & $0.0167^{\star * *}$ \\
\hline & & $(2.73)$ \\
\hline \multirow[t]{2}{*}{ LN_a } & 0.0004 & 0.0009 \\
\hline & $(0.25)$ & $(0.52)$ \\
\hline \multirow[t]{2}{*}{ Lev } & $0.0008^{\star * *}$ & $0.0008^{\star * *}$ \\
\hline & $(5.69)$ & $(5.15)$ \\
\hline \multirow[t]{2}{*}{ ROA } & 0.0004 & 0.0005 \\
\hline & $(1.30)$ & $(1.38)$ \\
\hline \multirow[t]{2}{*}{ ReceiR } & $0.0157^{\star}$ & $0.0166^{*}$ \\
\hline & $(1.67)$ & $(1.72)$ \\
\hline \multirow[t]{2}{*}{ Netprofit } & $-2.40 e-13$ & $-2.73 e-13$ \\
\hline & $(-0.84)$ & $(-0.85)$ \\
\hline \multirow[t]{2}{*}{$\mathrm{Tq}$} & $0.0123^{* * *}$ & $0.0119^{* * *}$ \\
\hline & $(7.91)$ & $(7.35)$ \\
\hline \multirow[t]{2}{*}{ Stateshr } & 0.0002 & 0.0002 \\
\hline & $(1.30)$ & $(1.30)$ \\
\hline \multirow[t]{2}{*}{ age } & -0.0001 & -0.0002 \\
\hline & $(-0.38)$ & $(-0.78)$ \\
\hline \multirow[t]{2}{*}{ gender } & -0.0067 & -0.0075 \\
\hline & $(-1.39)$ & $(-1.51)$ \\
\hline \multirow[t]{2}{*}{ tenure } & $-0.0025^{\star * *}$ & $-0.0027^{\star * *}$ \\
\hline & $(-2.97)$ & $(-2.88)$ \\
\hline \multirow[t]{2}{*}{ education } & $-0.0033^{\star * *}$ & $-0.0031^{\star * *}$ \\
\hline & $(-2.99)$ & $(-2.69)$ \\
\hline \multirow[t]{2}{*}{ N_director } & $-0.0027^{* * *}$ & $-0.0026^{\star *}$ \\
\hline & $(-2.80)$ & $(-2.46)$ \\
\hline \multirow[t]{2}{*}{ N_manager } & $-0.0025^{\star * *}$ & $-0.0026^{* * *}$ \\
\hline & $(-4.02)$ & $(-4.00)$ \\
\hline \multirow[t]{2}{*}{ N_supervisor } & -0.0029 & -0.0028 \\
\hline & $(-1.33)$ & $(-1.33)$ \\
\hline \multirow[t]{2}{*}{ meeting } & 0.0003 & 0.0002 \\
\hline & $(0.60)$ & $(0.34)$ \\
\hline _cons & 0.0460 & 0.0427 \\
\hline
\end{tabular}




\begin{tabular}{ccc}
\hline & $(1.41)$ & $(1.28)$ \\
$\mathrm{N}$ & 14297 & 13732 \\
INDUSTRY & YES & YES \\
YEAR & YES & YES \\
\hline
\end{tabular}

Notes: OLS with standard errors clustered by listed company. ${ }^{*} \mathrm{p}<0.1 ;{ }^{* *} \mathrm{p}<0.05 ;{ }^{* * *} \mathrm{p}<0.01$.

is associated with the $\mathrm{CFO}$, which means $\mathrm{CFO}$ is more willing to cooperate with the CEO, then to a certain extent, will increase the CEO's power in the company. Second, with the increase in CEO power, it will foster the CEO to actively optimistic "irrational" emotions, which may produce excessive self-confidence. And excessive self-confidence may lead to business investment behavior distortion, and will have a significant negative impact on future business performance. Meanwhile, Negative effects on performance can induce radical earnings management (Luo Jin and Li Yanxi, 2012) [21].

If the manager has higher pay ratio and stronger power, he or she is more likely to produce excessive self-confidence (Ferris et al., 2013; Bi Xiaofang et al., 2015) [22] [23]. We chose the relative salary index-CEO pay divided by the salary of all executives-as CEO overconfident alternative variables. If the relative salary is higher, the CEO is overconfident. The result is shown in Table 9.

Table 9 shows intermediate mechanism analysis result.

The first and third columns of Table 9 show that there is a significant positive correlation between the $\mathrm{CEO} / \mathrm{CFO}$ relevance and the CEO's overconfidence, and that the CEO's overconfidence does have a significant positive correlation with the degree of corporate earnings management, which is in line with our expectations. Then, we add the $\mathrm{CEO}$ overconfidence as an intermediate variable. Results As shown in forth column, the coefficient of CEO overconfidence and CEO/CFO correlation is both significant and positive (See Table 9).

\section{Conclusions}

We analyze the influence of the $\mathrm{CEO} / \mathrm{CFO}$ relevance on the quality of corporate accounting information based on the existence of appointment system in China's listed companies. Empirical study finds: 1) if there is a company with CEO and $\mathrm{CFO}$ relevance, the level of earnings management will be higher; 2) the $\mathrm{CEO} / \mathrm{CFO}$ relevance degree still has a significant and positive impact on the earnings management level of listed companies after considering the company's operating conditions, the CEO's personal background and the level of corporate supervision; 3 ) the $\mathrm{CEO} / \mathrm{CFO}$ relevance has a more significant and positive impact on corporate earnings management in larger companies or state-owned companies; 4) the implementation of equity incentive and CEO served as chairman both are significant positive moderation effect on the relationship between the $\mathrm{CFO} / \mathrm{CFO}$ relevance and the corporate earnings management level; 5) CEO overconfidence, as an intermediate variable, is not only significantly influenced 
Table 9. Intermediate mechanism.

\begin{tabular}{|c|c|c|c|c|}
\hline & (1) & (2) & (3) & (4) \\
\hline & over & absEM & absEM & absEM \\
\hline \multirow[t]{2}{*}{ con } & $0.0071^{\star * *}$ & $0.0053^{\star *}$ & & $0.0052^{\star *}$ \\
\hline & (3.31) & $(2.58)$ & & $(2.54)$ \\
\hline \multirow[t]{2}{*}{ over } & & & $0.0077^{\star * *}$ & $0.0076^{* * *}$ \\
\hline & & & $(2.79)$ & $(2.80)$ \\
\hline \multirow[t]{2}{*}{ LN_a } & $-0.0141^{\star * *}$ & $-0.0047^{\star * *}$ & $-0.0041^{\star * *}$ & $-0.0041^{\star * *}$ \\
\hline & $(-10.64)$ & $(-3.60)$ & $(-3.05)$ & $(-3.08)$ \\
\hline \multirow[t]{2}{*}{ Lev } & 0.0001 & $0.0010^{* * *}$ & $0.0010^{\star * *}$ & $0.0010^{* * *}$ \\
\hline & $(1.48)$ & $(3.52)$ & $(3.51)$ & $(3.53)$ \\
\hline \multirow[t]{2}{*}{$\mathrm{ROA}$} & $0.0001^{\star *}$ & 0.0003 & 0.0003 & 0.0003 \\
\hline & $(2.00)$ & (1.15) & (1.14) & (1.13) \\
\hline \multirow[t]{2}{*}{ ReceiR } & $-0.0171^{\star}$ & 0.0023 & 0.0034 & 0.0030 \\
\hline & $(-1.72)$ & $(0.10)$ & $(0.15)$ & $(0.14)$ \\
\hline \multirow[t]{2}{*}{ Netprofit } & $2.05 \mathrm{e}-13$ & $-2.23 e-13$ & $-2.36 \mathrm{e}-13$ & $-2.31 \mathrm{e}-13$ \\
\hline & $(1.40)$ & $(-1.08)$ & $(-1.16)$ & $(-1.12)$ \\
\hline \multirow[t]{2}{*}{$\mathrm{Tq}$} & $0.0019^{\star *}$ & $0.0113^{\star \star *}$ & $0.0112^{\star * *}$ & $0.0112^{* * *}$ \\
\hline & $(2.02)$ & $(8.17)$ & $(8.12)$ & $(8.14)$ \\
\hline \multirow[t]{2}{*}{ Stateshr } & $-0.0001^{\star * *}$ & 0.0002 & 0.0002 & 0.0002 \\
\hline & $(-2.71)$ & $(1.33)$ & $(1.32)$ & $(1.34)$ \\
\hline \multirow[t]{2}{*}{ _cons } & $0.4529^{\star * *}$ & $0.1065^{\star * *}$ & $0.0942^{* * *}$ & $0.0902^{\star * *}$ \\
\hline & (16.09) & $(3.57)$ & $(2.98)$ & $(2.91)$ \\
\hline $\mathrm{N}$ & 14141 & 14297 & 14297 & 14297 \\
\hline
\end{tabular}

Notes: OLS with standard errors clustered by listed company. ${ }^{*} \mathrm{p}<0.1 ;{ }^{* *} \mathrm{p}<0.05 ;{ }^{* *} \mathrm{p}<0.01$.

by the $\mathrm{CEO} / \mathrm{CFO}$ relevance, but also significantly and positively impact on the corporate earnings management.

The CEO and CFO are both of great significance on the company's accounting information quality and corporate governance. While, CEO/CFO strong correlation may damage the company's information quality in a variety of circumstances. Our results also show that excessive intimacy between CEO and CFO may damage the quality of corporate accounting information. And then it can damage the interests of shareholders and investors, affect the information, and ultimately lead to improper allocation of financial resources. Therefore, in corporate governance, the company should reduce the possibility of CEO's "cronyism", and CEO should avoid or reduce the authority to appoint CFO

We studied the impact of $\mathrm{CEO} / \mathrm{CFO}$ relevance and corporate earnings management, but there are still some shortcomings to be improved. Firstly, the $\mathrm{CEO} / \mathrm{CFO}$ relevance discussed in this article refers only to the linkages based on the appointment system, but it does not exclude the relevance of the previous 
social network link. It is necessary for future research to consider this association. Secondly, we only consider the relationship between CEO and CFO on the company's information quality and governance impact, but we do not join the CFO personal background. Finally, the data collected by hand, especially CEO/ CFO relevance, may be biased. These problems and deficiencies left to future research to gradually resolve.

\section{Conflicts of Interest}

The author declares no conflicts of interest regarding the publication of this paper.

\section{References}

[1] Hambrick, D.C. and Mason, P.A. (1984) Upper Echelons: The Organization as a Reflection of Its Top Managers. Social Science Electronic Publishing, 9, 193-206.

[2] He, W.F. and Liu, Q.L. (2010) Research on the Background Characteristics and Financial Restatement Behavior of Executives in China's Listed Companies. Management World, No. 7, 144-155.

[3] Bernile, G., Bhagwat, V. and Rau, P.R. (2017) What Doesn't Kill You Will Only Make You More Risk-Loving: Early-Life Disasters and CEO Behavior. Journal of Finance, 72, 167-206. https://doi.org/10.1111/jofi.12432

[4] Morse, A., Nanda, V. and Seru, A. (2011) Are Incentive Contracts Rigged by Powerful CEOs? Journal of Finance, 66, 1779-1821. https://doi.org/10.1111/j.1540-6261.2011.01687.x

[5] Coles, J.L., Daniel, N.D. and Naveen, L. (2007) Co-Opted Boards: Causes and Consequences. Social Science Electronic Publishing, 1751-1796. https://doi.org/10.2139/ssrn.972752

[6] Hidambaran, N.K., Kedia, S. and Prabhala, N. (2010) CEO-Director Connections and Corporate Fraud. Social Science Electronic Publishing.

[7] Dikolli, S.S., Mayew, W.J. and Sethuraman, M. (2016) The CEO-CFO Relationship and CEO Compensation. Social Science Electronic Publishing.

[8] Lo, K. (2008) Earnings Management and Earnings Quality. Journal of Accounting \& Economics, 45, 350-357. https://doi.org/10.1016/j.jacceco.2007.08.002

[9] Liu, H.L., Wang, C.F. and Wu, L.S. (2014) Decision-Making Power Allocation, Earnings Management and Investment Efficiency. Economic Research, No. 8, 93-106.

[10] Zhou, D.H. (2014) CEO Power, Board Stability and Earnings Management. Financial Theory and Practice, No. 6, 45-52.

[11] Lisic, L.L., Neal, T.L., Zhang, I.X., et al. (2016) CEO Power, Internal Control Quality, and Audit Committee Effectiveness in Substance versus in Form. Contemporary Accounting Research, 33, 1199-1237. https://doi.org/10.1111/1911-3846.12177

[12] Khanna, V., Kim, E.H. and Yao, L.U. (2015) CEO Connectedness and Corporate Fraud. Journal of Finance, 70, 1203-1252. https://doi.org/10.1111/jofi.12243

[13] Landier, A., Aauvagnat, J. and Sraer, D. (2013) Bottom-Up Corporate Governance. Review of Finance, 17, 161-201. https://doi.org/10.1093/rof/rfs020

[14] Coles, J.L., Daniel, N.D. and Naveen, L. (2014) Co-Opted Boards. Review of Financial, 2, 1751-1796. https://doi.org/10.1093/rfs/hhu011

[15] Krishnan, G.V., Raman, K.K. and Yang, K. (2011) CFO/CEO-Board Social Ties, 
Sarbanes Oxley, and Earnings Management. Accounting Horizons, 25, 537-557.

[16] Liu, J.Y. (2013) Research on the Relationship between CEO and CFO Term Staggered and Accounting Information Quality. Chinese Investment, No. s1, 64.

[17] Jiang, F.X., et al. (2013) Whether the CEO and CFO Appointments Can Reduce Earnings Management. Management World, 1, 158-167.

[18] Dechow, P.M., Sloan, R.G. and Sweeney, A.P. (1995) Detecting Earning Management. Accounting Review, 7, 193-225.

[19] Jones, J.J. (1991) Earnings Management during Import Relief Investigations. Journal of Accounting Research, 29, 193-228. https://doi.org/10.2307/2491047

[20] Shivdasani, A. and Yermack, D. (1999) CEO Involvement in the Selection of New Board Members: An Empirical Analysis. Journal of Finance, 54, 1829-1853. https://doi.org/10.1111/0022-1082.00168

[21] Luo, J. and Li, Y. (2012) Managers Are Overconfident, Performance Decline and Earnings Management. Monthly Accounting, No. 36, 6-9.

[22] Ferris, S.P., Jayaraman, N. and Sabherwal, S. (2013) CEO Overconfidence and International Merger and Acquisition Activity. Journal of Financial and Quantitative Analysis, 48, 137-164. https://doi.org/10.1017/S0022109013000069

[23] Bi, X.F., Zhang, J.M. and Li, H.Y. (2015) Industrial Policy, Manager Overconfidence and Corporate Liquidity Risk. Accounting Research, No. 3, 57-63. 